\title{
POLYAKH AND OTHERS V. UKRAINE: ECONOMIC CONSEQUENCES OF NON- COMPLIANCE WITH THE CRITERIA OF LUSTRATION MEASURES COMPATIBILITY WITH THE RIGHT TO RESPECT FOR PRIVATE LIFE
}

\section{Olena M. Polivanova}

Assistant Professor, International and Comparative Law Department, Faculty of Law, Kyiv University of Law of the National Academy of Sciences of Ukraine, Kyiv, Ukraine

\section{Volodymyr Ye. Polivanov}

Assistant Professor, Department of Economics and Competition Policy, Faculty of Economics, Management and Psychology, Kyiv National University of Trade and Economics, Kyiv, Ukraine

\begin{abstract}
The aim of the article is to analyze, taking into consideration the economic consequences, the compatibility criteria for the application of lustration measures under the Law of Ukraine 'On Government Cleansing (Lustration)' of 2014 with article 8 of the 1950 Convention for the Protection of Human Rights and Fundamental Freedoms. Based on the Judgment of the European Court of Human Rights in 'Polyakh and Others v. Ukraine' of 17 October 2019 and its previous case-law on the compatibility of the measures applied to the applicants by the authorities of the Convention States in accordance with the legal acts on lustration with the right to respect for private life, the criteria for the compatibility of lustration measures application with the right to respect for private life in the conditions of democratic regime in Ukraine are defined and analyzed. It is confirmed that for the assessment of the alleged violations of article 8 the Court used the following criteria: whether the application of the lustration measures was in accordance with the law', whether it pursuits a legitimate aim, whether the measure of lustration was 'necessary in a democratic society' answering a 'pressing social need', whether the application of the lustration measures was proportionate to the legitimate aim pursued and whether the reasons given by the national authorities to justify it are 'relevant and sufficient'. The
\end{abstract}


Polyakh and others v. Ukraine: economic consequences of non-compliance with the criteria of lustration measures compatibility with the right to respect for private life

analysis of the above-mentioned criteria may help to reduce the rate of probable adverse economic impact of the lustration measures application and improve their mechanisms both in Ukraine and Europe in general.

Keywords: European Court of Human Rights, Polyakh case, Lustration measures, Article 8, Criteria of compatibility

Cite this Article: Olena M. Polivanova and Volodymyr Ye. Polivanov, Polyakh and others v. Ukraine: economic consequences of non-compliance with the criteria of lustration measures compatibility with the right to respect for private life, International Journal of Management, 11 (6), 2020, pp. 544-559.

http://iaeme.com/Home/issue/IJM?Volume=11\&Issue $=6$

\section{INTRODUCTION}

Article 46 of the Convention for the protection of human rights and fundamental freedoms of 1950 (ECHR, Convention) contains the obligation of the Council of Europe member-states to comply with the judgments of the European Court of Human Rights (ECtHR, Court) [1]. Moreover, having ratified the Convention, Ukraine became obliged to execute the judgments of the Court in compliance with the requirements of the right to a fair trial [2]. At the same time, the annual expenditures of the state budget of Ukraine for the execution of the decisions of the Court are insufficient to carry out the full repayment of the existing debt and constantly decreasing. According to the State Treasury Service of Ukraine as of 16 October 2018, more than 152 thousand court decisions/judgments worth more than UAH 4.2 billion had to be enforced, while the Law of Ukraine 'On the State Budget of Ukraine for 2018' provided only for UAH 500 million on these costs [3]. It is clear that the complexity of the economic situation in Ukraine and the limited financial resources of the state do not allow to repay the debt on all court decisions/judgments guaranteed by the state and, accordingly, requires debt restructuring. The same tendency is seen in 2020. UAH 74269.7 million provided for the servicing of domestic debt obligations in 2019 [4] were reduced to UAH 21034.8 million in 2020 [5], which confirmed the existence of a financial problem with the execution of ECtHR judgments. Despite this fact, the Law of Ukraine 'On Government Cleansing (Lustration)' (LGC) of 17 October 2014, the lustration measures application under which has recently been recognized incompatible with article 8 of the Convention in respect of all five applicants in the case 'Polyakh and others v. Ukraine' (Polyakh, Judgment), remains in force. The case concerns the dismissal of five civil servants (applications No. 58812/15, 53217/16, 59099/16, 23231/18 and 47749/18) under the LGC [1]. Having held that there has been a violation of articles 6.1 and 8 of the Convention, the Court, on the basis of article 41 of the Convention, ordered Ukraine to pay to each of the applicants EUR 5,000 in respect of non-pecuniary damage and compensate EUR 1,500 to the first applicant together with EUR 300 to the second to fifth applicants each [1]. The Judgment has become final on 24 February 2020 [1].

Undoubtedly, the application of the LGC raised deep public concern and a number of lustrated high-ranking Ukrainian officials appealed to the administrative courts of Ukraine searching for their renewal in office [6]. As to the information of the Sixth Administrative Appeal Court [7], as of July 15, 2015, the administrative district courts received 746 cases and materials related to the application of the said law. And administrative courts either ruled in favour of the applicants [8] or rejected their claims [9, 10]. In one of the court's decisions it was even stated that the LGC is inconsistent with the Constitution of Ukraine, undermining the prerogative of the Constitutional Court of Ukraine to make such a conclusion [11].

It is notably, that the accordance of the LGC with the Constitution of Ukraine has not been examined by the Constitutional Court of Ukraine (CCU) yet. Notwithstanding the fact that on 
18 March 2015 the CCU passed a decision to open constitutional proceedings in the case of the constitutional submission of 47 People's Deputies of Ukraine regarding the conformity of some provisions of the LGC with the Constitution of Ukraine (constitutionality), during almost 5 years that have elapsed since the opening of the constitutional proceedings, the CCU has repeatedly postponed the case, noting that it will continue its consideration at one of the next plenary sessions. In 2020, the final decision on this issue has not been made although section 75 of the Law of Ukraine on the CCU of 13 July 2017 provides that constitutional proceedings must be completed within six months of the ruling opening such proceedings [12].

Delivering the Judgment caused resonance in Ukraine. The media perceived it as a criticism of the LGC [13] and as the instruction received from the authoritative international judicial institution on the need to abolish it [14-16]. In fact, the Court assessed the application of the lustration measures provided for by the LGC in the specific cases of the applicants. And, since the Court's judgments are a source of law in Ukraine [17], the Judgment can be a key one in determining the criteria for the application of lustration measures under the LGC so that the violation of the right to respect for private life enshrined in the Convention does not take place. Moreover, taking into consideration the fact that the Court of Human Rights' previous practice connected with assessment of compatibility of the lustration measures application with article 8 of the Convention concerned mainly post-communist lustration [1] of the countries of Central and Eastern Europe [18-26] (the period of transition from a totalitarian communist regime to democracy [1], the Judgment in Polyakh today unprecedentedly deals with the new understanding of lustration using anti-corruption measures in democratic regime. Therefore, the comprehensive analysis of the Court's criteria for finding that there has been a violation of article 8 of the Convention in the new circumstances in the absence of a Constitutional Court of Ukraine's decision on accordance of the LGC with the Constitution of Ukraine [27], can both facilitate effective judicial review of disputes over the LGC's application at the national level to reduce the rate of probable adverse economic impact caused by the mass appeal of persons who have suffered from the application of lustration measures in accordance with the LGC to the Court to protect their right to respect for private life and, consequently, improve the mechanisms of lustration measures application both in Ukraine and Europe in general.

\section{LITERATURE REVIEW}

Notwithstanding the fact that the research made was primarily based on the practice of the European Council and the Court of Human Rights dealing with the assessment of the compatibility of the post-communist lustration measures application in the countries of Central and Eastern Europe [18-26, 28] (the period of transition from a totalitarian communist regime to democracy [1], with the right to respect for private life under article 8 of the Convention, the scientific platform for the article comprised the works [29-38] dedicated to specific aspects of the Court's practice related to article 8 of the Convention. It is essential not to leave without attention the researches [39-46], which mainly address the problematic issues of applying postcommunist lustration legislation in the countries of Central and Eastern Europe. However, in Ukraine comprehensive studies of the compatibility criteria of lustration measures application with the right to respect for private life under Article 8 of the Convention of the period of 'young Ukrainian democracy' $[1,47]$ are almost nonexistent. In view of this, the article attempts to carry out such a study and fill in the gap of Ukrainian science of European law.

\section{METHODS}

The article employs the descriptive qualitative research of the Council of Europe's documents on lustration (with the special attention given to those commenting the lustration measures application on the basis of the LGC in Ukraine) and the Court of Human Rights' practice on the compatibility of the lustration measures application with the Convention for Human Rights 
and Fundamental Freedoms of 1950. In particular, the authors' observations are stemmed from the judgments of the Court involving the applicability of article 8 of the Convention on the right to respect for private life. Using comparative contextual analyses of the Court of Human Rights' cases in which it considered on the compatibility of the lustration measures application on the basis of the legislative acts adopted mostly in Central and Eastern European states in postcommunist period and the case 'Polyakh and others $v$. Ukraine' of 2019 the criteria of the lustration measures application compatibility with the right to respect for private life under article 8 of the Convention in the democratic period are defined and analysed.

\section{DISCUSSION}

In [1], the Court of Human Rights concluded that the application of lustration measures to the applicants constituted an interference with their right to respect for private life, noting, however, that such interference is compatible with article 8 of the Convention only if it has been carried out 'in accordance with the law' and was 'necessary in a democratic society'. These two criteria are traditionally used by the Court when defining whether the Convention states have exceeded their powers in interfering with a person's private life within the meaning of article 8.2 of the Convention [48]. At the same time, the Court took into consideration the specificity of first four applicants' situation due to the fact, as it was pointed out by the Venice Commission, that the LGC, on the basis of which the lustration measures were applied, deals with two distinct periods - the period of totalitarian communist rule and the period when President Yanukovych was in power (as the first four applicants' cases concern the latter period) [1]. Therefore, in the assessment of the alleged violation of article 8, the Court used the criteria developed by it in cases concerning post-communist lustration and those it deemed were necessary in the circumstances of the present case: whether the application of the lustration measures was 'in accordance with the law', whether it pursuits a legitimate aim, whether the measure of lustration was 'necessary in a democratic society' answering a 'pressing social need', whether the application of the lustration measures was proportionate to the legitimate aim pursued and whether the reasons given by the national authorities to justify it are 'relevant and sufficient'.

\subsection{Accessibility and foreseeability of the lustration law as thresholds for the lustration measures to be applied 'in accordance with the law' under article 8 of the Convention}

The Court's previous practice has established that interference with the right to respect for a person's private life is exercised 'in accordance with the law' if:

- a legal basis of the interference is the law - not an administrative practice which could be changed at any time as it was noticed by the Court in [49] or non-binding instructions (Home Office Guidelines which were neither legally binding nor directly publicly accessible) as in [50];

- the law in question is clear, foreseeable, and adequately accessible [51], it is formulated with sufficient precision [52] that the persons concerned may anticipate the extent of the adverse effects of their actions contrary to its provisions [1, 53-55]; it must be sufficiently foreseeable in its terms to give individuals an adequate indication as to the circumstances in which, and the conditions on which, the authorities are entitled to resort to measures affecting their rights under the Convention [56]; the applicants must have been able to foresee to a reasonable degree, at least with the advice of legal experts, that they would be regarded as covered by the law [57];

- the law in question contains a measure of protection against arbitrariness by public authorities [33]. 
In [1], the Court emphasized that the legal basis of the measures applied to the applicants was the domestic law of Ukraine - the LGC. Pursuant to the LGC, 'government cleansing (lustration)' is a ban imposed by the law or a court judgment on particular individuals taking certain positions (serving) in central and local government authorities (except for elective positions). This lustration measure aims at keeping away from public governance persons who made decisions, took action or inaction (and/or contributed to their taking) facilitating the usurpation of power by the former President of Ukraine Viktor Yanukovych and seeking to undermine the foundations of national security and defense or violate human rights and freedoms. According to the LGC, government cleansing is based on the following principles: the rule of law and lawfulness; openness, transparency and public accessibility; the presumption of innocence; individual liability; and the guarantee of the right to defense [1].

In the Court's view, the LGC was accessible (since it was published) and sufficiently foreseeable - since it contained a list of positions that were subject to restrictive measures [1]. It should be noted that the LGC provides for the dismissal from their positions in the civil service of two categories of persons. The first category are the persons who occupied cumulatively at least one year such positions in the period from February 25, 2010 to February 22, 2014 (paragraph 1 of article 3 of the LGC) or holding such positions for any period of time from November 21, 2013 to February 22, 2014 (paragraph 2 of article 3 of the LGC); any person appearing in this category is subjected to a 'ten-year ban' - the ban for ten years (until 16 October 2024) from occupying positions in the civil service or local government and directors of State-owned companies working in the defense sector or those providing administrative services on behalf of government agencies (section 2 and section 1.3 of the LGC) [1]. The second category includes the persons, for whom the grounds for application of the LGC need to be established by a judicial decision, based on the official's individual actions rather than on him or her occupying certain positions; those persons are subject to the "ten-year ban' or 'fiveyear ban' - to be counted from the moment the relevant judicial decision becomes final [1]. At the same time, the LGC requires all state and local government officials to submit to their superiors, specified in the law, within the timeframe approved by the relevant governmental bodies, a statement, declaring whether any of the restrictions in the LGC apply to them and providing consent to the statement being checked (article 4.1 and 2.1.1-2.1.10) (declaration) [1]. The names of the officials and the positions from which they have been dismissed shall be entered in the Unified State Register (Lustration Register) of such persons - a publicly accessible online database, established and maintained by the Ministry of Justice of Ukraine (article 7 of the LGC) [1].

However, the previous practice of the Court confirms that to be sufficiently foreseeable the lustration law should not only contain the list of such positions, but include provisions on the specifically created commission for the lustration administering [55]. The same was stated by the Venice Commission in its Final Opinion on the LGC. Referring to the 1996 Guidelines [58], it stressed that the responsibility for carrying out the lustration process should be removed from the Ministry of Justice of Ukraine; it should be entrusted to an independent commission of distinguished citizens nominated by the head of state and approved by parliament [47], with the active involvement of the civil society [47, 59]. Nonetheless, the amendments to the LGC, submitted to the Venice Commission by the Government of Ukraine for its Final Opinion on the LGC, instead, provided for the creation of the central executive body, replacing the Ministry of Justice in its responsibilities on lustration [47]. And it was immediately criticized, inter alia, because it cannot be independent forming a part of the executive power, and there is no involvement by either the President of Ukraine or the Verkhovna Rada of Ukraine in the process of nomination and appointment of the head, his or her deputies [47], which contravenes the above mentioned criterion used by the Venice Commission. The other reason of criticism was the lack of the LGC's compatibility with the Constitution of Ukraine: according to article 85 of 
the Constitution, one of the powers the Verkhovna Rada has is the appointment or election, removal from offices, giving consent to the appointment and removal from offices of the persons in cases provided for in the Constitution; as the Executive Body is not mentioned in the Constitution, a constitutional amendment would thus be needed [47]. All these inaccuracies of the LGC create doubts on its foreseeability.

Moreover, in [55], to conclude that the 2006 Act (which had specifically been put in place to regulate the exposure of staff members and collaborators of the former security services) is sufficiently foreseeable, the Court took into account that the Act laid down in detail the procedure to be followed by the Commission and that it does not have any discretion in the matter: the 2006 Act indicated clearly the conditions for and the circumstances in which the Commission would check someone for affiliation with the former security services and expose him or her if it found records attesting to such affiliation [55]. The LGC, in contrast, provides that persons occupying certain positions submit to their chiefs or agency written statements on whether they are (or are not) subject to the ban under the law, consent to screening and publishing of information about them [47] and the Cabinet of Ministers of Ukraine schedules the screening. Thus, lustration is a decentralized process which means that individuals are screened within their own office or agency [47]. In the Venice Commission's view, "[s]ince Ukraine had never experienced lustration in the past, there is a risk that the practice under the Law, which is to be implemented by a range of public agencies, could either lack uniformity or open space for settling accounts on a personal/political basis... The situation is particularly problematic due to the fact that up to know, the judicial review of lustration decisions has been de facto inoperative and the decisions in individual cases are thus not subject to any external control" [47].

Consequently, due to the fact that the LGC does not prescribe in detail the procedure to be followed by the specially established independent commission created with participation of the president and the parliament of Ukraine and to the fact that the process of lustration is still under the administering of the executive power of Ukraine there is a probability that the LGC lacks the characteristics to be called sufficiently foreseeable law in the meaning of article 8 of the Convention. And, it is unclear why the Court in Polyakh did not take into consideration its previous practice or the conclusions of the Venice Commission on the issue.

\subsection{Compatibility of the lustration measures application with the legitimate aim criterion}

Legitimate aim criterion for lustration measures application compatibility with Article 8 of the Convention was widely used by the Court in its previous practice concerning post-communist lustration in other Central and Eastern European States [18, 23, 55]. In those cases, the Court held that lustration measures pursue the legitimate aims of the protection of national security and public safety, the prevention of disorder, and the protection of the rights and freedoms of others [1, 24-26]. At the same time, as it was mentioned by the Venice Commission, the lustration measures in Ukraine pursue not only the aim of protecting the society from threats to the newly established democratic regime, but also of cleansing the public administration of individuals who had engaged in large-scale corruption [47]. That is why, without denying that those measures prescribed by the LGC are justified to address the two goals identified above in the relevant period in Ukrainian, the Court had to ascertain whether those measures (much broader in scope and applied in a context different from that prevailed in the other Central and Eastern European countries when they implemented their lustration programs) in the specific circumstances of the applicants cases, pursued a legitimate aim within the meaning of Article 8.2 of the Convention [1]. 
The Court had doubts on whether the lustration measures applied to the applicants on the basis of the LGC in [1] pursued a legitimate aim. Firstly, it compared the threat to the functioning of the democratic institutions in Ukraine posed by the persons subject to the LGC measures and the threat posed by former (alleged) collaborators of the secret services of the totalitarian regimes in Europe in its previous cases [1]. It noted that the dismissals in Ukraine appear to have been based rather on a collective liability of individuals employed by State institutions during President Yanukovych's time in power. And the specific functions those individuals performed or their link to the antidemocratic tendencies and developments which occurred during that period have not been taken into consideration [1]. Secondly, referring to its case law and Council of Europe's documents concerning lustration [22, 58, 60], the Court reiterated that lustration, as well as the impugned measures provided by the LGC, may not be used for punishment, retribution or revenge [1]. At the same time, in the Court's view, the farreaching nature of the measures applied to the applicants, combined with the highly charged language of the LGC's aims, 'raise the possibility that some of those measures may have been motivated, at least in part, by vindictiveness towards those associated with the previous governments' [1]. Thirdly, the fact that information on the measures application to the applicants was immediately made public expresses serious doubts about the compatibility of that aspect of the lustration procedure under the LGC with the Convention [1]. As it was earlier stated in [26], the publication of the information on the lustration measure application (a nonfinal Commission decision) prior it had been examined by the courts pursues no legitimate aim within the meaning of Article 8.2 of the Convention. Almost the same was stressed by the Venice Commission in its Interim Opinion on the LGC [59].

Relying on the conclusions of the Court in [1], it may be stated that in the heart of the lustration measures application compatibility with the legitimate aim criterion, implied in Article 8 of the Convention, in democratic context lies the assessment of the threat posed by the persons subject to the lustration measures - taking into account their specific functions and the link to antidemocratic tendencies. If the aims of lustration measures application could have been achieved 'by less intrusive means such as, where possible, following an individual assessment, removing the applicants from their positions of authority and transferring them, where possible, to less sensitive positions' [1], there application may rise the possibility that they could have been used with the intend of vindictiveness, which is contrary to the legitimate aims set under the right to respect for private life. Finally, the application of a lustration measure may be made public only after it becomes final. The contrary shall not justify the application of the measure by the legitimate aim.

\subsection{Compatibility of the lustration measures application in Ukraine with the criterion of 'necessity in a democratic society'}

The right to respect for private life enshrined in Article 8 of the Convention is not absolute [61, 62]. According to the Court's practice, Convention States' interference may be justified if it is 'necessary in a democratic society' [63]. The Court has held that the adjective 'necessary' lies somewhere between 'indispensable' and such expressions as 'admissible', 'ordinary', 'useful', 'reasonable' or 'desirable' [63]. In Sunday Times case, the Court of Human Rights stressed that '[i]t must $\ldots$ be decided whether the 'interference' complained of corresponded to a 'pressing social need', whether it was 'proportionate to the legitimate aim pursued', [and] whether the reasons given by the national authorities to justify it are "relevant and sufficient.' [64]. Thus, firstly, to be justified as being 'necessary in democratic society' the interference in the right to respect for private life must be justified by a 'pressing social need' relating to one or more of the legitimate aims [65]. In determining whether such a need exists, attention must be paid to the particular facts of the case and to the circumstances prevailing in the given country 
Polyakh and others v. Ukraine: economic consequences of non-compliance with the criteria of lustration measures compatibility with the right to respect for private life

at the time [66, 67]. The state's action must also be based upon 'an acceptable assessment of the relevant facts' [68].

In [1], the Court, referring to the Venice Commission's assessment [59], cited two legitimate aims pursued by the lustration measures application: protecting the society from individuals who, due to their past behaviour, could pose a threat to the newly established democratic regime and cleansing the public administration of individuals who had engaged in large-scale corruption [1]. Notwithstanding the fact that there were doubts of the Court on whether the lustration measures application pursued the legitimate aim, the Court in [1] proceeded its examination of the question on whether the lustration measures application were 'necessity in a democratic society' [1].

Determining whether the lustration measures application answered a 'pressing social need' and was proportionate to the legitimate aims of lustration, defined by the Venice Commission, the Court paid attention to the particular facts of the case and to the circumstances prevailing in Ukraine at the time.

According to the Government of Ukraine's position in [1], lustration was an urgent demand of society and a necessary condition for the transition to a qualitatively new level of public administration. The Government stated that Mr Yanukovych's years in office had been characterised by the neglect of the values of a constitutional democratic State. In [1] the Court had even concluded that there had been political control over the appointment and dismissal of judges. Mr Yanukovych's rule had come to an end as a result of the EuroMaidan protests [1]. In the Ukrainian Government's view, as the result of Mr Yanukovych's activities and his escape to Russia, the Russian authorities had been able to annex Crimea and instigate an armed insurgency in the Donetsk and Luhansk Regions through the so-called 'Donetsk People's Republic' and 'Luhansk People's Republic' [1]. The LGC had been enacted in order to restore trust in the State authorities after those developments [1].

At the same time, while it is for the national authorities to make the initial assessment of a necessity of the interference into the right to private life of a person, the final evaluation as to whether the reasons cited for the interference are relevant and sufficient remains subject to review by the Court for conformity with the requirements of the Convention [69]. The Court outlined that in the circumstances of negative developments concerning respect for democracy, the rule of law and human rights [70], and the rule of government which was perceived undemocratic and engaged in large-scale systemic corruption $[1,47]$ the measures against civil servants personally associated with the above-mentioned negative developments, were, in principle, justified [1]. However, notwithstanding the fact that post-communist Convention States have a broad margin of appreciation in choosing how to deal with the legacy of totalitarian regimes [55], even in cases involving transition from totalitarian rule to democracy the Court has been confronted with restrictive measures of less broad scope [1] and found violations of various provisions of the Convention where lustration measures had been applied without sufficient individualization [22, 24]. For instance, in [71], the Court concluded that the ban on the applicant seeking employment in various branches of the private sector, in application of the Lithuanian lustration law, despite the legitimacy of the aims pursued by that ban, constituted a disproportionate measure and a violation of Article 14 of the Convention taken in conjunction with Article 8, as, inter alia, there were no objective materials in the case file verified by the domestic courts to indicate that the applicant poses a current danger to national security if he was to be employed in certain sectors of private business [71]. In [22], the Court considered that the section 5.5 of the Parliamentary Elections Act concept targeting former 'officers' of the KGB was too broad and that a restriction of the electoral rights of a member of that group should take a case-by-case approach which would allow their actual conduct to be taken into account. In [24], one of the reasons for the Court to conclude on the 
disproportionate interference in the applicant's right to respect for his private life was the absence of the procedure to assess the specific tasks performed by individual employees of the former security services in order to differentiate the danger they could possibly pose several years after the termination of their career in these institutions. In general, it has already been stressed by [58] in respect of the Convention States dismantling the heritage of former communist totalitarian systems and almost reiterated in the Venice Commission's Interim Opinion [59], that the measures of lustration are compatible with a democratic state under the rule of law if the guilt of a person concerned is proven on individual basis, not just based on the mere belonging to a category of public offices.

At the same time, in [1], the Court explained that the necessary individualization is not always indispensable at the level of each particular individual's case and may be done at the legislative level. The individualization on the legislative level was assessed by the Court in [55]. In that case the applicant, a lawyer and a former high ranking official in Bulgaria [55], claimed that a widely publicised decision exposing him as having been affiliated with the seventh department of the sixth directorate of State Security between 1982 and 1990 had stigmatised him and had deeply upset his private and social life in violation of Article 8 of the Convention. Assessing whether the Bulgarian authorities acted within their margin of appreciation, the Court outlined that in Bulgaria a system exposing affiliation was preceeded by the long period of lustration laws blocking and their criticism by the Constitutional Court [55]. The statute providing for that exposure was the fruit of much debate, and was passed by the legislature with cross-party support, including the provision especially aggrieving the applicant - the one concerning the types of records on the basis of which someone could be exposed as a collaborator [55]. The Constitutional Court of Bulgaria later examined the Act's constitutionality on the basis of arguments by various authorities and non-governmental organisations, all of which defended it. On the basis of the above-mentioned reasons the Court concluded on the broad margin of appreciation of the Bulgarian authorities in the applicant's case $[55,72,73]$. Furthermore, in the Court's view, the chosen statutory scheme was not at the fringes of the state's margin [55]. Exposure entailed no sanctions or legal disabilities and, as noted by the Constitutional Court of Bulgaria, it is not certain that it carries a universal social stigma either. Indeed, in contrast to, for instance, Lithuania and the former Yugoslav Republic of Macedonia [18, 25], in Bulgaria those concerned have not as a rule suffered ostracism; many of those exposed continue to be active in public life and since his exposure the applicant has continued to be involved in business and public life as well [55]. Moreover, unlike in Estonia [24], the Act, even after its amendments in 2012 and 2017, affected only those who have, since the fall of the regime, taken up posts of some importance in the public sector, or in parts of the private sector deemed to have special importance for society at large. Finally, accepting the legislative level individualization scheme of Bulgarian authorities, the Court took into account the fact that in Bulgaria not all of the files of the former security services had survived and it might have been feasible to assess the exact role of each of the people mentioned in them [55].

In [1], the lustration measures application did not involve any individual assessment of the applicants' conduct: it was never alleged that the applicants had themselves committed any specific acts undermining democratic governance, the rule of law, national security, defense or human rights. The Court of Human Rights stated that, in fact, they were dismissed by operation of law merely for having occupied certain relatively high-ranking positions in the civil service while Mr Yanukovych was the President of Ukraine [1]. At the same time, the Court of Human Rights either did not find the cogent reasons for the Ukrainian authorities to use the legislative level individualization scheme [1]. Among the decisive criteria for such a conclusion it mentioned the quality of parliamentary and judicial review of the legislative scheme, the severity of the measure involved and whether the legislative scheme is sufficiently narrowly tailored to address the pressing social need it seeks to address in a proportionate manner [1]. 
Polyakh and others v. Ukraine: economic consequences of non-compliance with the criteria of lustration measures compatibility with the right to respect for private life

In respect of the first criterion the Court primarily noted that the broad and very restrictive character of the lustration measures applied under the LGC required their discussion in the course of the parliamentary debates over the LGC which was not actually carried out [1]. Secondly, the Court indicated the lack of coherence between the LGC's proclaimed aims ('the presumption of innocence' and 'individual liability') and the rules it actually promulgated (the application of lustration measures without the individual assessment of the persons concerned conduct). Thirdly, the LGC has not been reviewed by the Constitutional Court of Ukraine yet which means the Court cannot benefit from its views on this point (in contrast to [74] or [55]).

Applying the second criterion the Court stressed that the legislative scheme under the LGC was significantly more broad and generalised than those adopted, for example, by Poland [75] or Latvia [20], which were limited in application to those who played an active role in the activities of the former authorities which were contrary to democracy [1]. In contrast, according to the LGC, the lustration measures could be applied even to a civil servant who had been appointed to his post a long time prior to Mr Yanukovych becoming President merely on the basis of the fact that he failed to resign from his post within a year of Mr Yanukovych's taking office [1]. The Court considered that career civil servants cannot be subjected to restrictive measures of such severity merely for remaining in their positions in the civil service following the election of a new head of State [1].

Referring to the third criterion the Court did not find the cogent explanation for the temporal frames set by the LGC [1]. The LGC appeared to be both a response to the negative results of the activities of all post-communist elites and, as the Government of Ukraine stressed, the key element in restoring public trust in the State authorities through the visible renewal of their personnel [1]. Along with that, the period from 1991 to 2010 (the most associated with the activities of all post-communist elites in Ukraine) was excluded from the scope of the LGC. And the one-year period as the key criterion for application of the LGC was also left without explanation [47]. Furthermore, neither the Constitutional Court's 2010 decision [1] cited by Ukraine as a key element of proof of the anti-democratic nature of Mr Yanukovych's rule, nor any other specific negative development of that period have not been given a role of the criteria of the lustration measures application under the LGC. Instead, the LGC attached the importance to Mr Yanukovych's taking office as the triggering element of the lustration application [1]. Finally, the Government of Ukraine neither has shown that there had been any irregularity in the applicants' appointment or retention in office (in support of its allegation on existing under Mr Yanukovych's rule of the pattern of placement in the civil service of corrupt individuals based merely on personal loyalty and in disregard of democratic procedures and values), nor applicants' involvement in any abuses of Mr Yanukovych's political opponents or EuroMaidan protesters [1].

The fourth applicant in [1] was dismissed and subjected to restrictive measures under the LGC because he had filed his lustration declaration four days late. Substantiating its position, the Court was not sure whether the fourth applicant would have been subjected to restrictive measures under the LGC if he had submitted a lustration declaration in time. The Court drew attention to its previous case-law, in which the duty of a person to file a declaration was directed to identify certain potentially hidden facts, such as covert cooperation with the security services of the former totalitarian regimes [21, 28, 73]. However, in the present case there was never any suggestion that there were any unknown facts in the fourth applicant's career which the declaration could reveal [1]. Therefore, the Court was unable to perceive how imposition of such a serious restrictive measure for a minor delay in filing such a technical statement could be seen as 'necessary in a democratic society' [1]. And the Court found that the measures applied to the applicant under the LGC were disproportionate to the trivial nature of the applicant's omission [1]. 
Lastly, the conformity of the lustration measures application was put in question by the following facts: the information on the applicants' removal from the civil service was made publicly available before they could obtain a review of such measures and even the ex post facto remedy available to the applicants operated with excessive delay which resulted in proceedings lasted for almost half of the total ten-year period of their exclusion [1].

The Court determined the timing of adoption and implementation of lustration measures as a key consideration in assessing their proportionality [1]. It stated, that such measures are, by their nature, temporary, and the objective necessity for them decreases over time [22]. For instance, in [22], the Court found the application of lustration legislation to the applicant after a ten-year career in independent Latvia incompatible with Article 3 of the Protocol 1 of the Convention. In [25], the fact that lustration legislation had been enacted sixteen years after transition to democracy was a relevant factor for the Court to find that the lustration measures applied to the applicant as a collaborator of the former secret police had been disproportionate. Likewise, the Court referred to [18], in which the fact that lustration measures had been applied nine and thirteen years after the applicants' departure from the KGB was a factor for the Court to rule on the violation of Article 14 of the Convention taken in conjunction with Article 8 . Even thirteen years ago, in [20], where the Court found no violation of Article 3 of Protocol No. 1, the Court already held that the Latvian parliament had to keep the statutory restriction on former Communist Party members under constant review, 'with a view to bringing [them] to an early end'.

In [1], the lustration measures were enacted and applied more than twenty-three years after Ukraine's transition from totalitarian communist rule to democracy. In the Court's view, implementation of restrictive measures of such seriousness not to alleged KGB agents, but to people who occupied positions in the Communist Party of the former USSR and of the Ukrainian SSR, in the absence of any suggestion of specific wrongdoing on their part, after such a long lapse of time requires a very strong justification [1]. The Court concluded that the Ukrainian authorities have failed to give such a justification [1].

The Court outlined that the disproportionate nature of the lustration measure is particularly pronounced in the fifth applicant's case as no serious argument has been made that the applicant, a local official working in agriculture, could conceivably pose a threat to the newly established democratic regime. The domestic authorities demonstrated total disregard for his rights [1].

\section{CONCLUSIONS}

The European Court of Human Rights found a violation of Article 8 of the Convention in Polyakh as, in its view, it has not been shown that the lustration measures application under the LGC in respect of any of the applicants was necessary in a democratic society.

Based on the conclusions in the case, the following key criteria for the application of lustration measures in the period of young Ukrainian democracy can be identified.

Lustration measures will be considered as having been applied in accordance with the law, if such law was accessible (published) and formulated with sufficient accuracy; the persons concerned could have foreseen the extent of the adverse effects of their actions contrary to its provisions; the law contained a remedy against arbitrariness of public authorities. To be sufficiently foreseeable in the meaning of article 8 of the Convention, the lustration law should prescribe in detail the procedure to be followed by the specially established independent commission created with participation of the president and the parliament of the state, with the active involvement of the civil society.

The lustration measures may be considered pursuing a legitimate aim if their use is justified by the need to protect the public from persons who, through their past behavior, could threaten 
the newly formed democratic regime or if they are aimed to purify public administration from those who have committed widespread corruption. In doing so, a prerequisite for assessing the compatibility of the purposes of the lustration measures application with the objectives recognized as legitimate is taking into account all the circumstances of the applicants' particular cases relating to the determination of the existence or absence of a violation of a specific article of the Convention and their 'necessity in a democratic society' in meaning of art. 8.2 of the Convention.

The necessity of lustration measures application in a democratic society is determined by their scope, nature and context. In the circumstances of negative developments concerning respect for democracy, the rule of law and human rights, and the rule of government which was perceived undemocratic and engaged in large-scale systemic corruption the measures against civil servants personally associated with the negative developments, may be, in principle, justified. At the same time, if the objectives of the application could be achieved in less intrusive ways, their likelihood to be motivated by vindictiveness against the persons involved in previous governments is rising and does not meet the criterion of 'necessity in a democratic society'. If the application of lustration measures to persons is based solely on the fact that they occupy certain relatively high positions during the rule of a particular government, irrespective of their functions, there is a risk that the state will exceed its powers by taking such measures. According to the European Court's standard, the application of lustration measures must be individualised - at the level of each individual case. Individualisation of lustration measures' use is also possible at the legislative level, however - in the presence of qualitative parliamentary and judicial reviews of such a legislative scheme. This takes into account the severity of the measures applied and whether the legislative scheme is sufficiently narrowly designed to meet the pressing social need, at the request of which it is applied on the basis of the principle of proportionality.

Lustration measures can be applied, if there is a clear explanation for their temporal frame - with reference to specific events or negative precedents of a particular government period of rule, where the key is to prove the applicants' identified relationship to specific negative events.

Publication of information about persons to whom lustration measures have been applied is possible only after they have exhausted the possibility of challenging such measures. At the same time, the remedies available must act without delay.

Lustration measures application to the person who did not file the lustration declaration within the terms stipulated by the law are proportional to the legitimate aim if the declaration disclosed certain potentially hidden facts about the person, obliged to submit it. Otherwise, imposition of such a severe restrictive measure for a minor delay in submitting a technical application cannot be considered as 'necessary in a democratic society'.

The timing of adoption and implementation of lustration measures is a key consideration in assessing their proportionality. Such measures are, by their nature, temporary, and the objective necessity for the restriction of individual rights resulting from this procedure decreases over time. Severe lustration measures adopted and implemented in twenty years after the transition from a totalitarian communist regime to democracy require very strong justification. In its absence, their application does not meet the criterion of necessity in a democratic society.

\section{REFERENCES}

[1] Case of Polyakh and Others v. Ukraine. App No. 58812/15. European Court of Human Rights, 2019. https://hudoc.echr.coe.int/eng\#\{\%22itemid\%22:[\%22001-196607\%22]\}

[2] Guide on Article 6 of the European Convention on Human Rights. Right to a fair trial (civil limb). European Court of Human Rights, 2019. https://www.echr.coe.int/Documents/Guide_Art_6_ENG.pdf 
[3] Regarding the results of consideration of the deputy's request of Yevtushko S. M. of 02.11.2018. Ministry of Justice of Ukraine, 2018.

[4] Expenditures of the state budget of Ukraine. Minfin, 2019. https://index.minfin.com.ua/ua/finance/budget/gov/expense/2019/

[5] Expenditures of the state budget of Ukraine. Minfin, 2020. https:/index.minfin.com.ua/ua/finance/budget/gov/expense/

[6] OASK received about 250 claims for lustration. Legal Newspaper, 2015. http://yurgazeta.com/golovna/oask-otrimav-blizko-250-pozoviv-shchodo-lyustraciyi-.html

[7] Analysis of the Practice of Application by the Administrative Courts of Some Provisions of the Law of Ukraine "On Purification of Power". Sixth Administrative Appeal Court. https://6aas.gov.ua/ua/law-library/court-practice/vishchij-administrativnij-sud-ukrajini/analizpraktiki-zastosuvannya-administrativnimi-sudami-okremikh-polozhen-zakonu-ukrajini-proochishchennya-vladi.html

[8] Case No. 640/18282/18. Sixth Administrative Appeal Court, 2019. http://reyestr.court.gov.ua/Review/83323436

[9] Case No. 826/14960/18. Sixth Administrative Appeal Court, 2019. http://reyestr.court.gov.ua/Review/83377213

[10] Case No. 826/9250/16. Sixth Administrative Appeal Court, 2019. http://reyestr.court.gov.ua/Review/82898119

[11] Case No. 826/18250/14. Sixth Administrative Appeal Court, 2019. http://reyestr.court.gov.ua/Review/83323619

[12] Law of Ukraine on the Constitutional Court of Ukraine. Legislation of Ukraine, 2017. https://zakon.rada.gov.ua/laws/show/2136-19

[13] The ECtHR has criticized the lustration of Yanukovych officials. Ukrainian Truth, 2019. https://www.pravda.com.ua/news/2019/10/17/7229284/

[14] "Servant of the People" has registered a bill to repeal the law on lustration. Espreso, 2019. https:/espreso.tv/news/2019/10/19/quotsluga_naroduquot_zareyestruvala_zakonoproekt_pro_s kasuvannya_zakonu_pro_lyustraciyu

[15] Lustration law repeal: The text of the bill appeared. Legal Newspaper, 2019. http://yurgazeta.com/golovna/skasuvannya-zakonu-pro-lyustraciyu-zyavivsya-tekst-zakonoproektu.html

[16] Ministry of Justice may consider repealing lustration law as an attempt to revenge odious persons. Radio Svoboda, 2019. https://www.radiosvoboda.org/a/news-minyustliustratsiya/30037235.html

[17] On the enforcement of decisions and the application of the case law of the European Court of Human Rights. Legislation of Ukraine, 2012. https://zakon.rada.gov.ua/laws/show/3477-15

[18] Case of Sidabras and Džiautas v. Lithuania. App No. 55480/00 and 59330/00. European Court of Human Rights, 2004. https://hudoc.echr.coe.int/eng\#\{\%22itemid\%22:[\%22001-61942\%22]\}

[19] Case of Turek v. Slovakia. App No. 57986/00. European Court of Human Rights, 2006. https://hudoc.echr.coe.int/eng\#\{\%22itemid\%22:[\%22001-72354\%22]\}

[20] Case of Ždanoka v. Latvia. App No. 58278/00. European Court of Human Rights, 2006. https://hudoc.echr.coe.int/eng\#\{\%22itemid\%22:[\%22001-72794\%22]\}

[21] Case of Bobek v. Poland. App No. 68761/01. European Court of Human Rights, 2007. https://hudoc.echr.coe.int/fre\# \{\%22itemid\%22:[\%22001-81677\%22]\}

[22] Chamber judgment Ādamsons v. Latvia. App No. 3669/03. European Court of Human Rights, 2008. https://hudoc.echr.coe.int/eng-press\# \{\%22itemid\%22:[\%22003-2403964-2593721\%22]\}

[23] Decision Naidin v. Romania. App No. 38162/07. European Court of Human Rights, 2014. https://hudoc.echr.coe.int/eng-press\#\{\%22itemid\%22:[\%22003-3271674-3651937\%22]\}

[24] Case of Sõro v. Estonia. App No. 22588/08. European Court of Human Rights, 2015. https://hudoc.echr.coe.int/eng\#\{\%22itemid\%22:[\%22001-156518\%22]\} 
Polyakh and others v. Ukraine: economic consequences of non-compliance with the criteria of lustration measures compatibility with the right to respect for private life

[25] Case of Ivanovski v. the Former Yugoslav Republic of Macedonia. App No. 29908/11. European Court of Human Rights, 2016. https://hudoc.echr.coe.int/eng\#\{\%22itemid\%22:[\%22001$160219 \% 22]\}$

[26] Case of Karajanov v. the former Yugoslav Republic of Macedonia. App No. 2229/15. European Court of Human Rights, 2017. https://hudoc.echr.coe.int/eng\#\{\%22itemid\%22:[\%22001$172563 \% 22]\}$

[27] CCU Agenda for December 2-5, 2019 (project). Constitutional Court of Ukraine, 2019. http://www.ccu.gov.ua/publikaciya/poryadok-dennyy-zasidan-ksu-na-2-5-grudnya-2019-rproyekt?fbclid=IwAR2MsoIzlJgoQTvZfL7BR5pduudXA4GglZivyzZxPzW-QZWPrBbvHrFQfE

[28] Case of Luboch v. Poland. App No. 37469/05. European Court of Human Rights, 2008. https://hudoc.echr.coe.int/eng\# \{\%22itemid\%22:[\%22001-84373\%22]\}

[29] Arai-Takahashi, Y. The margin of appreciation doctrine and the principle of proportionality in the jurisprudence of the ECHR. Antwerp: Intersentia, 2002.

[30] Cameron, I. An introduction to the European convention on human rights (4th ed.). Uppsala: Lustus Förlag, 2002.

[31] Gomez-Arostegui, H. T. Defining private life under the European Convention on human rights by referring to reasonable expectations. California Western International Law Journal, 35(2), 2005, pp. 153-202.

[32] Feldman, D. The Developing Scope of Article 8 of the European Convention on Human Rights. European Human Rights Law Review, 3, 1997, pp. 265-274.

[33] Kilkelly, U. The right to respect for private and family life. A guide to the implementation of Article 8 of the European Convention on Human Rights. Human rights handbooks, No. 1. Strasbourg: Council of Europe, 2001.

[34] Loucaides, L. G. Personality and Privacy under the European Convention on Human Rights. In Essays on the developing law of human rights. Dordrecht: Martinus Nijhoff Publishers, 1995, pp. 83-107.

[35] Merrils, J. G. The development of international law by the European Court of Human Rights. Manchester: Manchester University Press, 1988.

[36] Ost, F. The Original Canons of Interpretation of the European Court of Human Rights. In: M. Delmas-Marty (ed.) The European Convention for the protection of human rights: international protection versus national restrictions. Dordrecht: Martinus Nijhoff Publishers, 1992, pp. 283318.

[37] Roagna, I. Protecting the right to respect for private and family life under the European Convention on Human Rights: Council of Europe human rights handbooks. Strasbourg: Council of Europe, 2012.

[38] van Dijk, P. and van Hoof, F. Theory and practice of the European convention on human rights (3rd ed.). Boston: Kluwer Law and International, 1998.

[39] David, R. Lustration and Transitional Justice: Personnel Systems in the Czech Republic, Hungary, and Poland. Philadelphia, PA: University of Pennsylvania Press, 2011.

[40] Killingsworth, M. Lustration after totalitarianism: Poland's attempt to reconcile with its Communist past. Communist and Post-Communist Studies, 43(3), 2010, pp. 275-284.

[41] Letki, N. Lustration and democratisation in East-Central Europe. Europe-Asia Studies, 54(4), 2002, pp. 529-552.

[42] Dvořáková, V. and Milardović, A. (eds.) Lustration and Consolidation of Democracy and the Rule of Law in Central and Eastern Europe. Zagreb: CPI, 2007.

[43] Misztal, B. A. How not to deal with the past: lustration in Poland. European Journal of Sociology/Archives Européennes de Sociologie, 40(1), 1999, pp. 31-55.

[44] Ravaitytè, J. Evaluation of the lustration policy in Lithuania. Politologija, 77(1), 2015, pp. 49100. 
[45] Vuks, Y. V. Lustration Legislation in Eastern Europe and Its Meaning for the Western World. Master's thesis. Arlington: University of Texas at Arlington, 2014.

[46] Williams, K., Fowler, B. and Szczerbiak, A. Explaining lustration in Central Europe: a 'postcommunist politics' approach. Democratization, 12(1), 2005, pp. 22-43.

[47] Final Opinion on the law on government cleansing (lustration law) of Ukraine. Council of Europe, 2015. https://www.venice.coe.int/webforms/documents/default.aspx?pdffile=CDL$\mathrm{AD}(2015) 012-\mathrm{e}$

[48] Guide on Article 8 of the European Convention on Human Rights. European Court of Human Rights, 2019. https://www.echr.coe.int/Documents/Guide_Art_8_ENG.pdf

[49] Case of Malone v. The United Kingdom. App No. 8691/79. European Court of Human Rights, 1984. https://hudoc.echr.coe.int/eng\#\{\%22itemid\%22:[\%22001-57533\%22]\}

[50] Case of Khan v. the United Kingdom. App No. 35394/97. European Court of Human Rights, 2000. https://hudoc.echr.coe.int/eng\#\{\%22itemid\%22:[\%22001-58841\%22]\}

[51] Case of Silver and Others v. The United Kingdom. App No. 5947/72; 6205/73; 7052/75; $7061 / 75 ; 7107 / 75 ; 7113 / 75 ;$ 7136/75. European Court of Human Rights, 1983. https://hudoc.echr.coe.int/eng\#\{\%22itemid\%22:[\%22001-57577\%22]\}

[52] Case of Lebois v. Bulgaria. App No. 67482/14. European Court of Human Rights, 2017. https://hudoc.echr.coe.int/eng\#\{\%22itemid\%22:[\%22001-177698\%22]\}

[53] Case of Margareta and Roger Andersson v. Sweden. App No. 17202/04. European Court of Human Rights, 1992. https://hudoc.echr.coe.int/eng\#\{\%22itemid\%22:[\%22001-57748\%22]\}

[54] Case of Shimovolos v. Russia. App No. 30194/09. European Court of Human Rights, 2011. https://hudoc.echr.coe.int/eng\#\{\%22tabview\%22:[\%22document\%22],\%22itemid\%22:[\%2200 $1-105217 \% 22]\}$

[55] Decision Haralambi Borisov Anchev v. Bulgaria. App No. 38334/08 and 68242/16. European Court of Human Rights, 2017. https://hudoc.echr.coe.int/eng\#\{\%22itemid\%22:[\%22001$180084 \% 22]\}$

[56] Case of Fernández Martínez v. Spain. App No. 56030/07. European Court of Human Rights, 2014. https://hudoc.echr.coe.int/eng\#\{\%22itemid\%22:[\%22001-145068\%22]\}

[57] Case of Dubská and Krejzová v. the Czech Republic. App No. 28859/11 and 28473/12. European Court of Human Rights, 2014. https://hudoc.echr.coe.int/eng/\#\{\%22itemid\%22:[\%22001$148632 \% 22]\}$

[58] Measures to dismantle the heritage of former communist totalitarian systems. Doc. 7568. Parliamentary Assembly, 1996. http://assembly.coe.int/nw/xml/xref/x2h-xrefviewhtml.asp?fileid $=7506$ \&lang $=$ en

[59] Interim Opinion on the law on government cleansing (lustration law) of Ukraine. Council of Europe, 2014. https://www.venice.coe.int/webforms/documents/default.aspx?pdffile=CDL$\mathrm{AD}(2014) 044-\mathrm{e}$

[60] Resolution 1096 (1996). Measures to dismantle the heritage of former communist totalitarian systems. Parliamentary Assembly, $1996 . \quad \mathrm{http} / / / \mathrm{semantic}-$ pace.net/tools/pdf.aspx?doc=aHR0cDovL2Fzc2VtYmx5LmNvZS5pbnQvbncveG1sL1hSZWY vWDJILURXLWV4dHIuYXNwP2ZpbGVpZD0xNjUwNyZsYW5nPUVO\&xsl=aHR0cDovL 3NlbWFudGljcGFjZS5uZXQvWHNsdC9QZGYvWFJ1Zi1XRC1BVC1YTUwyUERGLnhzbA $==\&$ xsltparams $=$ ZmlsZWlkPTE2NTA3

[61] Gerards, J. How to improve the necessity test of the European Court of Human Rights. International Journal of Constitutional Law, 11(2), 2013, pp. 466-490. https://doi.org/10.1093/icon/mot004

[62] McHarg, A. Reconciling human rights and the public interest: conceptual problems and doctrinal uncertainty in the jurisprudence of the European Court of Human Rights. Modern Law Review, 62(5), 1999, pp. 671-696. 
Polyakh and others v. Ukraine: economic consequences of non-compliance with the criteria of lustration measures compatibility with the right to respect for private life

[63] Greer, S. The exceptions to Articles 8 to 11 of the European Convention on Human Rights. Strasbourg: Council of Europe Publishing, 1997.

[64] Case of Sunday Times v. United Kingdom. App No. 6538/74. European Court of Human Rights, 1979. https://hudoc.echr.coe.int/rus\#\{\%22itemid\%22:[\%22001-57584\%22]\}

[65] Case of Observer and Guardian v. United Kingdom. App No. 13585/88. European Court of Human Rights, 1991. https://hudoc.echr.coe.int/eng\#\{\%22itemid\%22:[\%22001-57705\%22]\}

[66] Case of Lingens v. Austria. App No. 9815/82. European Court of Human Rights, 1986. https://hudoc.echr.coe.int/eng\#\{\%22itemid\%22:[\%22001-57523\%22]\}

[67] Case of Ezelin v. France. App No. 11800/85. European Court of Human Rights, 1991. https://hudoc.echr.coe.int/eng\#\{\%22itemid\%22:[\%22001-57675\%22]\}

[68] Case of Oberschlick v. Austria. App No. 11662/85. European Court of Human Rights, 1991. https://hudoc.echr.coe.int/tur\#\{\%22itemid\%22:[\%22001-57716\%22]\}

[69] Case of Chapman v. the United Kingdom. App No. 27238/95. European Court of Human Rights, 2001. https://hudoc.echr.coe.int/eng\#\{\%22itemid\%22:[\%22001-59154\%22]\}

[70] Opinion on the constitutional situation in Ukraine. Venice Commission, 2010. https://www.venice.coe.int/webforms/documents/default.aspx?pdffile=CDL-AD(2010)044-e

[71] Case of Žičkus v. Lithuania. App No. 26652/02. European Court of Human Rights, 2009. https://hudoc.echr.coe.int/eng\#\{\%22fulltext\%22:[\%2226652/02\%22],\%22documentcollectioni d2\%22:[\%22GRANDCHAMBER\%22,\%22CHAMBER\%22],\%22itemid\%22:[\%2200192069\%22]\}

[72] Case of Aksu v. Turkey. App No. 4149/04 and 41029/04. European Court of Human Rights, 2012. https://hudoc.echr.coe.int/eng\#\{\%22itemid\%22:[\%22001-109577\%22]\}

[73] Case of Perinçek v. Switzerland. App No. 27510/08. European Court of Human Rights, 2015. https://hudoc.echr.coe.int/eng\#\{\%22itemid\%22:[\%22001-158235\%22]\}

[74] Case of Animal Defenders International v. The United Kingdom. App No. 48876/08. European Court of Human Rights, 2013. https://hudoc.echr.coe.int/eng\#\{\%22itemid\%22:[\%22001$119244 \% 22]\}$

[75] Case of Matyjek v. Poland. App No. 38184/03/. European Court of Human Rights, 2006. https://hudoc.echr.coe.int/eng\#\{\%22itemid\%22:[\%22001-80219\%22]\}

[76] Ebenezer Olutide. Bamidele, Timothy O. Mosaku, and Olabosipo I. Fagbenle, Causes of NonCompliance with Public Procurement Act, 2007 among Federal and States Tertiary Institutions in Project Delivery in Southwest, Nigeria, International Journal of Mechanical Engineering and Technology, 10(3), 2019, pp. 1431-1440. 